\title{
Effect of the Properties of Chalcopyrite Semiconductors on the Physical and Optical Parameters of Cell Layers with CIGS
}

\author{
Merwan Rachedi ${ }^{1}$, Abdelkrim Merad ${ }^{2}$, Giulio Lorenzini ${ }^{3 *}$, Hijaz Ahmad $^{4}$, Younes Menni ${ }^{1}$, Houari Ameur ${ }^{5}$, Ibtissem \\ Sifi $^{1}$ \\ ${ }^{1}$ Unit of Research on Materials and Renewable Energies, Department of Physics, Faculty of Sciences, Abou Bekr Belkaid \\ University, P.O. Box 119, Tlemcen 13000, Algeria \\ ${ }^{2}$ Solid State Physics Team, Theoretical Physics Laboratory, Faculty of Sciences, University of Tlemcen, B.P. 119, Tlemcen \\ 13000, Algeria \\ ${ }^{3}$ Department of Engineering and Architecture, University of Parma, Parco Area delle Scienze, 181/A, Parma 43124, Italy \\ ${ }^{4}$ Department of Basic Science, University of Engineering and Technology, Peshawar 25000, Pakistan \\ ${ }^{5}$ Department of Technology, University Centre of Naama, P.O. Box 66, Naama 45000, Algeria
}

Corresponding Author Email: Giulio.lorenzini@unipr.it

https://doi.org/10.18280/rcma.310201

Received: 7 January 2021

Accepted: 15 April 2021

\section{Keywords:}

solar materials, CuInGaSe2 solar cells, cell layers with CIGS, chalcopyrite semiconductors, conversion efficiency

\begin{abstract}
In this paper, the impact of various buffers of applying components on the effectiveness of CuInGaSe 2 solar cells is studied numerically. The SCAPS software is employed to achieve the investigation. The main parameters of the inspected devices are: the photovoltaic conversion effectiveness $(\eta)$, the filling factor $(\mathrm{FF})$, short-circuit current (Jsc), and open circuit voltage (Voc). These photovoltaic parameters are analyzed vs. the thickness in the various buffer layers under study. The numerical findings revealed that the most significant conversion effectiveness (23.4\%) of the CIGS solar cell is obtained with the CdS buffer layer. An attempt is conducted to improve this efficiency by using the SCAPS and by optimizing the two electrical and technological parameters of the three layers ( $\mathrm{ZnO}, \mathrm{CdS}, \mathrm{CIGS})$.
\end{abstract}

\section{INTRODUCTION}

The natural chalcopyrite is characterized by an electronic structure similar to the $n$-type semiconductor. This is why it is not expected to achieve considerable current at low anodic potentials until a 'breakdown' potential is reached. This characteristic is highly encountered in electrochemistry, where low currents are given at a potential up to $1.0 \mathrm{~V}$. Trends in capacitance, limiting currents, and photocurrents are also the characteristics of the chalcopyrite [1].

Hadjab et al. [2] examined the electronic and structural characteristics of chalcopyrite semiconducting material Copper-Indium-Gallium-Selenium. They reported that the investigated material is very suitable in photovoltaic and optoelectronic systems [2]. Madhuri et al. [3] indicated that $\mathrm{CuInxGa}(1-\mathrm{x}) \mathrm{Se}_{2}$ (CIGS) is a renowned absorbing material that may be highly efficient in solar cells. Its efficiency of $22.6 \%$ is considered as very competitive to $\mathrm{Si}$ based solar cells. CIGS nanoparticles are known by their significant surface to volume ratio and may be used in photovoltaic systems at low temperature. Mandati and Sarada [4] used the pulsed current electrochemical deposition to fabricate CIGS films. Ramasamy et al. [5] illustrated in their work that the chalcopyrite $\mathrm{CuIn}(1-\mathrm{x}) \mathrm{GaxSe}_{2}$ (CIGS) thin films are photoelectrochemically active with p-type conductivity.

Kotbi et al. [6] confirmed that the $\mathrm{CuInGaS}_{2}$ (CIGS) thin films have a chalcopyrite structure. Their analysis showed that the rise of the gallium proportion yields an increase in the optical band gap energy of the films within the range [1.501.56] $\mathrm{eV}$ and an augmentation in the electrical properties in the sheet resistivity. Sheu et al. [7] determined the electrical and structural characteristics of polycrystalline CIGS thin films by varying the $\mathrm{Cu} /(\mathrm{In}+\mathrm{Ga})$ ratio with the help of a co-evaporation technique.

The family of chalcopyrites are well known by their significant performance for solar cells, as reported by JägerWaldau [8]. The chalcopyrites allow stimulated emission/laser action, since they show direct bandgaps and narrow luminescent bands. Tai et al. [9] obtained considerable performance of $22.3 \%$ with $\mathrm{Cu}(\mathrm{In}, \mathrm{Ga})(\mathrm{Se}, \mathrm{S})_{2}$ solar cells. Generally, CIGS PV layers are fabricated under considerable temperatures $\left(>450^{\circ} \mathrm{C}\right)$ [10]. Akhavan et al. [11] employed CIGS nanocrystals and their technique allowed $3.1 \%$ power conversion efficiency.

The structure of CIGS is chalcopyriteat ambient pressure. Pluengphon et al. [12] proposed the high-pressure phase transitions similar to those of the $\mathrm{CuInSe}_{2}$ phase transitions. Lara-Lara and Fernández [13] reported that the performance of the semiconductor $\mathrm{Cu}$ (In, Ga) $\mathrm{Se}_{2}$ (CIGS) in photovoltaic systems exceeds $20 \%$ by the physical vapor deposition. They reported also that there are various approaches to make the CIGS absorber layer, and the electro deposition technique is the most suitable for many economic and technical aspects. technique to make it for different technical and reasons.

The study conducted by Park et al. [14] showed that the CIGSSe is more efficient that the CIGS under standard 
irradiation conditions, where the energy conversion efficiencies were 8.81 and $8.28 \%$ for CIGSSe and CIGS, respectively. Jheng et al. [15] found an efficiency higher than $8.6 \%$ for the systems constructed with thin films of CIGS.

Fu et al. [16] used electrochemical measurements and that the CIGS thin film is of a p-type. Dharmadasa [17] suggested a novel concept for the development of CIGS material to be used in solar cells. The work conducted by Liang et al. [18] revealed that CIGS films grown at 450 and $500^{\circ} \mathrm{C}$ have better stoichiometric composition. Van Puyvelde et al. [19] suggested using flexible polymer substrates instead of rigid glass in the fabrication of $\mathrm{Cu}$ (In, Ga) $\mathrm{Se}_{2}$ (CIGS) thin-film solar cells to reduce the cost.
Other interesting works on GICS devices may be found in the literature (Sobayel et al. [20], Li et al. [21], Farooq et al. [22], Sharbati et al. [23], Bouchama et al. [24], Saifullah et al. [25], Mallem et al. [26], Ding et al. [27], Procel et al. [28], Richter et al. [29], Tao et al. [30], Ok et al. [31], Rajani et al. [32], Singh et al. [33], and Jay et al. [34]). They also presented in Table 1.

In the present paper, the photovoltaic structure to be studied is based on a CIGS absorber with an alternative buffer layer such as $\mathrm{ZnO}$ as a window layer and a front contact in Molybdenum (Mo) taken as front contact. This configuration is used for a CIGS solar cell.

Table 1. PV cells with vs. solar material structures

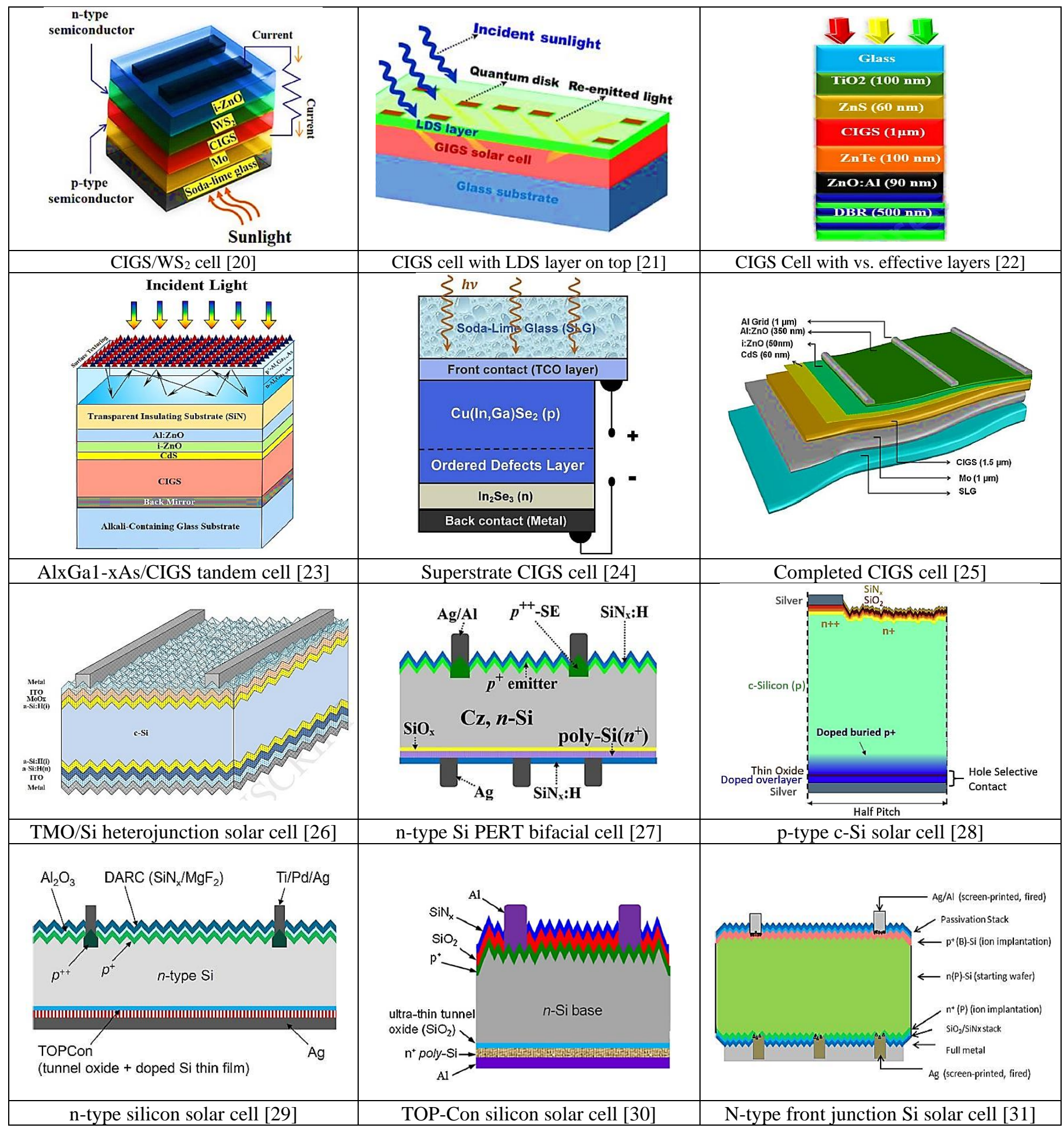




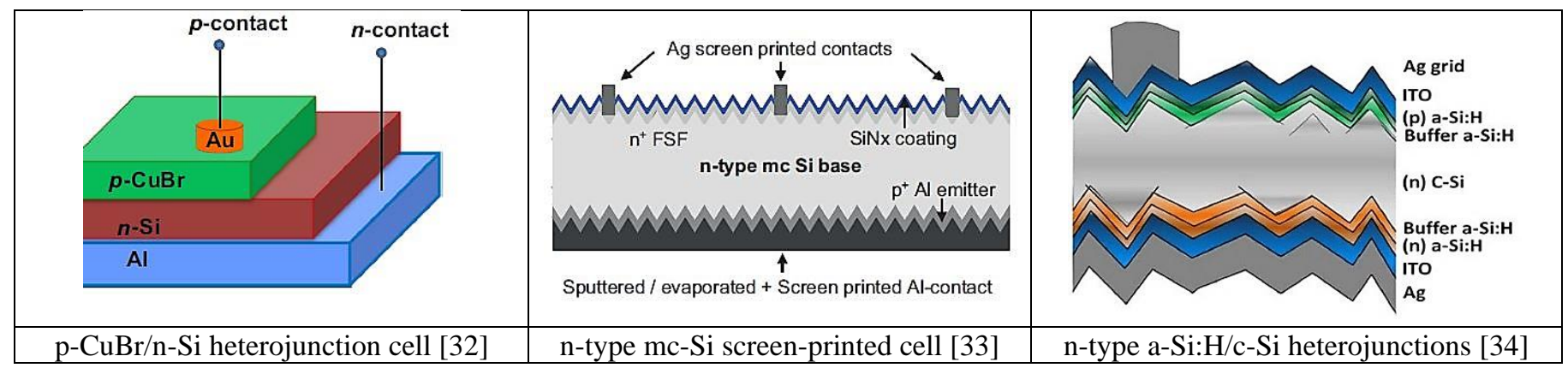

Table 2. Parameters of the solar cell using SCAPS simulation

\begin{tabular}{|c|c|c|c|}
\hline Physical and optical parameters & 1 ${ }^{\text {stlayer: CIGS }}$ & $2^{\text {nd }}$ layer: CdS & $3^{\text {rd layer: } \mathrm{ZnO}}$ \\
\hline Thickness $(\mu \mathrm{m})$ & 3.000 & 0.050 & 0.200 \\
\hline Bandgap (eV) & 1.100 & 2.400 & 3.300 \\
\hline Electron affinity $(\mathrm{eV})$ & 4.500 & 4.200 & 4.450 \\
\hline Dielectric permittivity (relative) & 13.600 & 10.000 & 9.000 \\
\hline CB effective density of states $\left(1 / \mathrm{cm}^{3}\right)$ & $6.595 \mathrm{E}+17$ & $2.500 \mathrm{E}+18$ & $9.999 \mathrm{E}+16$ \\
\hline VB effective density of states $\left(1 / \mathrm{cm}^{3}\right)$ & $1.855 \mathrm{E}+19$ & $9.000 \mathrm{E}+18$ & $9.950 \mathrm{E}+19$ \\
\hline Electron thermal velocity $(\mathrm{cm} / \mathrm{s})$ & $1.000 \mathrm{E}+7$ & $1.000 \mathrm{E}+7$ & $1.000 \mathrm{E}+7$ \\
\hline Hole thermal velocity $(\mathrm{cm} / \mathrm{s})$ & $1.000 \mathrm{E}+7$ & $1.000 \mathrm{E}+7$ & $1.000 \mathrm{E}+7$ \\
\hline Electron mobility $\left(\mathrm{cm}^{2} / \mathrm{Vs}\right)$ & $1.000 \mathrm{E}+2$ & $1.000 \mathrm{E}+2$ & $1.000 \mathrm{E}+2$ \\
\hline Hole mobility $\left(\mathrm{cm}^{2} / \mathrm{Vs}\right)$ & $2.500 \mathrm{E}+1$ & $2.500 \mathrm{E}+1$ & $2.500 \mathrm{E}+1$ \\
\hline Shallow uniform acceptor density ND $\left(1 / \mathrm{cm}^{3}\right)$ & $2.200 \mathrm{E}+18$ & $2.200 \mathrm{E}+18$ & $2.200 \mathrm{E}+18$ \\
\hline Shallow uniform acceptor density NA $\left(1 / \mathrm{cm}^{3}\right)$ & $1.800 \mathrm{E}+19$ & $1.800 \mathrm{E}+19$ & $1.800 \mathrm{E}+19$ \\
\hline
\end{tabular}

\section{THE CIGS-BASED SOLAR CELL BY SCAPS}

The structure developed by Gloeckler [35] was used a reference for this work. The diagram of the thin-film CIGS solar cell is highlighted in Figure 1.

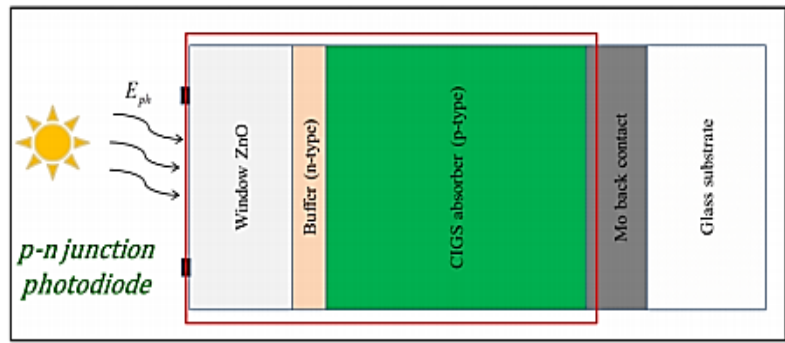

Figure 1. CIGS solar cell with a thin film

\subsection{Physical and optical parameters of the cell layer with CIGS}

The parameters of the $\mathrm{ZnO}, \mathrm{CdS}$ and CIGS materials used in the simulation of the solar cell are presented in Table 2. The efficiency of the simulated device (Figure 2) was found to be about $17.71 \%$, so an attempt is made to increase this value by changing some parameters.

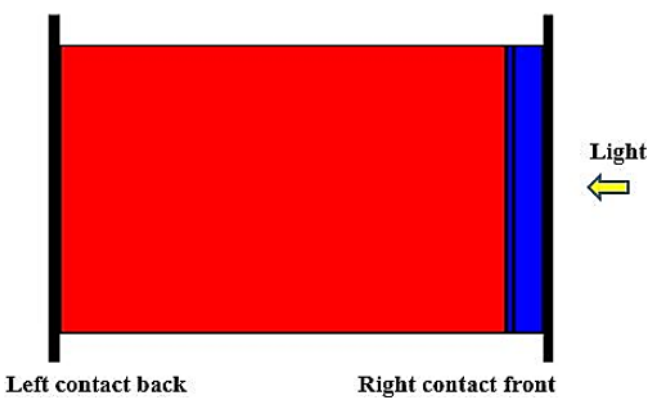

Figure 2. The CIGS-based solar cell

\section{THE CIGS-BASED SOLAR CELL MODIFIED}

The two electrical (doping) and technological (thickness) parameters of the three layers ( $\mathrm{ZnO}, \mathrm{CdS}, \mathrm{CIGS}$ ) were optimized to increase the overall efficiency of the device. In this article, we are interested in studying the impact of layers thicknesses on the physical and optical parameters of the CIGS-based solar cell.

- Physical and optical parameters of the $1^{\text {st }}$ layer: Modified CIGS

- Thickness: $3.00 \rightarrow 3.9 \mu \mathrm{m}$

- Physical and optical parameters of the $2^{\text {nd }}$ layer: Modified CdS

- Thickness: $0.050 \rightarrow 0.020 \mu \mathrm{m}$

- Physical and optical parameters of the $3^{\text {rd }}$ layer: Modified $\mathrm{ZnO}$

- Thickness: $0.20 \rightarrow 0.043 \mu \mathrm{m}$

So, the new cell becomes (Figure 3 ):

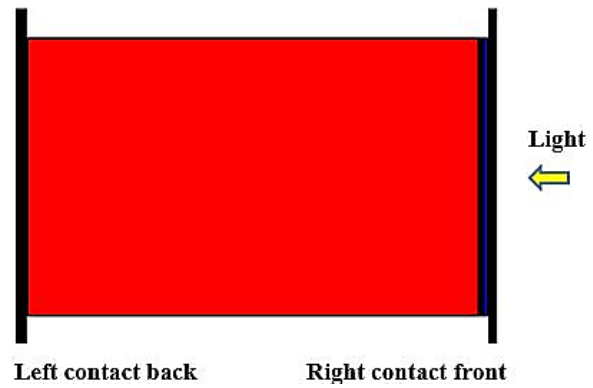

Figure 3. CIGS-based solar cell modified

\subsection{Model validation}

The photovoltaic characteristics of the CIGS-based solar cell are summarized in Table 3. Our results obtained numerically and those of Ref. [35] are compared. As remarked, the validation indicates the accuracy of our results. 
Table 3. Solar cell parameters deduced from calculated IV-curve

\begin{tabular}{ccc}
\hline Solar cell parameters & Results of [35] & Simulation results of our work \\
\hline Open circuit voltage Voc (Volt) & 0.64 & 0.79 \\
Short-circuit current Jsc $\left(\mathrm{mA} / \mathrm{cm}^{2}\right)$ & 33.72 & 35.20 \\
Filling factor FF $(\%)$ & 81.57 & 83.86 \\
Efficiency $\eta(\%)$ & 17.71 & 23.40 \\
\hline
\end{tabular}

Table 4. Effect of different thicknesses of CIGs

\begin{tabular}{|c|c|c|c|c|c|c|c|c|}
\hline \multirow{2}{*}{$\begin{array}{c}\text { Thickness } \\
\text { X } \\
\text { (CIGs) }\end{array}$} & \multicolumn{2}{|c|}{ Efficiency $\eta(\%)$} & \multicolumn{2}{|c|}{ Filling factor FF (\%) } & \multicolumn{2}{|c|}{$\begin{array}{l}\text { Short-circuit current Jsc } \\
\qquad\left(\mathrm{mA} / \mathrm{cm}^{2}\right)\end{array}$} & \multicolumn{2}{|c|}{$\begin{array}{c}\text { Open circuit voltage } \\
\operatorname{Voc}(\mathrm{V})\end{array}$} \\
\hline & $\begin{array}{l}\text { Reference } \\
\text { structure }\end{array}$ & $\begin{array}{c}\text { New } \\
\text { structure }\end{array}$ & $\begin{array}{l}\text { Reference } \\
\text { structure }\end{array}$ & $\begin{array}{c}\text { New } \\
\text { structure }\end{array}$ & $\begin{array}{l}\text { Reference } \\
\text { structure }\end{array}$ & $\begin{array}{c}\text { New } \\
\text { structure }\end{array}$ & $\begin{array}{l}\text { Reference } \\
\text { structure }\end{array}$ & $\begin{array}{c}\mathrm{Ne} \\
\text { Structure }\end{array}$ \\
\hline 0.5 & 13.12 & 16.68 & 77.22 & 78.30 & 28.572725 & 29.053462 & 0.5945 & 0.7332 \\
\hline 1 & 15.30 & 19.93 & 79.80 & 81.74 & 30.919552 & 31.886486 & 0.6203 & 0.7646 \\
\hline 1.5 & 16.41 & 21.42 & 80.79 & 82.83 & 32.186582 & 33.268252 & 0.6311 & 0.7773 \\
\hline 2 & 17.06 & 22.26 & 81.20 & 83.34 & 32.935091 & 34.057531 & 0.6378 & 0.7841 \\
\hline 2.5 & 17.46 & 22.76 & 81.42 & 83.62 & 33.408870 & 34.549177 & 0.6417 & 0.7880 \\
\hline 3 & 17.71 & 23.08 & 81.57 & 83.75 & 33.720319 & 34.869094 & 0.6439 & 0.7904 \\
\hline 3.5 & 17.88 & 23.29 & 81.66 & 83.83 & 33.929208 & 35.081990 & 0.6453 & 0.7920 \\
\hline 3.9 & 17.97 & 23.40 & 81.70 & 83.86 & 34.046703 & 35.200983 & 0.6461 & 0.7928 \\
\hline
\end{tabular}

\section{RESULTS AND DISCUSSION}

\subsection{Effect of the CIGS absorber layer}

The absorber is the part of the cell in which the photons will be converted into electron-hole pairs. In this case, it is a p-type semiconductor of the family I-III-VI, the different variants of which have already been studied lead to the following general formula: (Cu, Ag) (In, Ga, Al) (Se, S, Te $)_{2}$. Substitution of $\mathrm{Cu}$ with silver, of indium with gallium or aluminum, selenium by sulfur or tellurium, makes it possible to modify the material properties such as its prohibited bandwidth. The most developed compound in research and industry is $\mathrm{Cu}$ (In, Ga) $\mathrm{Se}_{2}$. Figure 4 indicates the changes in the efficiency vs. the thickness of the CIGS layer. In addition, Table 4 summarizes the effect of different thicknesses of CIGs.

These results show an increased efficiency with the rise of the thickness of the CIGS absorbent layer.

The results of the changes in the filling factor vs. the thickness of the CIGS layer are given in Figure 5. The figure shows an augmentation in the filling factor with the rise of the thickness of the CIGS absorbent layer.

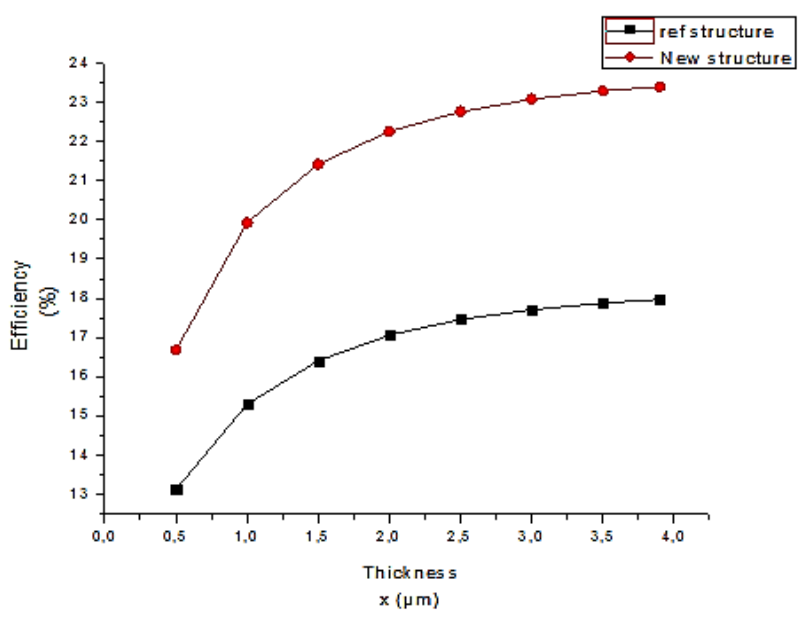

Figure 4. Changes in the efficiency vs. the thickness of the CIGS layer
The changes in the short-circuit current vs. the thickness of the CIGS layer is provided in Figure 6, where an augmentation in the short-circuit current was found when the thickness of the CIGS absorbent layer increases.

Figure 7 reveals the changes in the open circuit voltage vs. the thickness of the CIGS layer. In addition, the effect different thicknesses of CdS are given in Table 5. It is well illustrated that the open circuit voltage increases when the thickness of the CIGS absorbent layer increases.

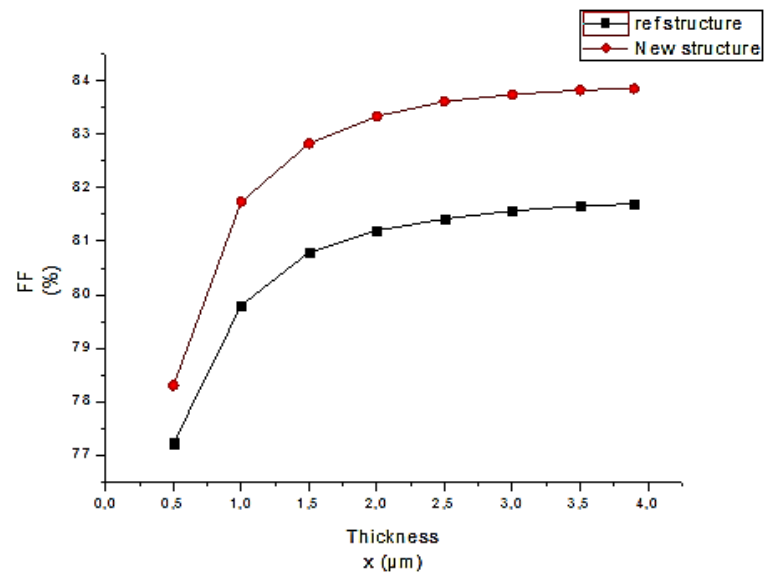

Figure 5. The filling factor vs. the thickness of CIGS layer

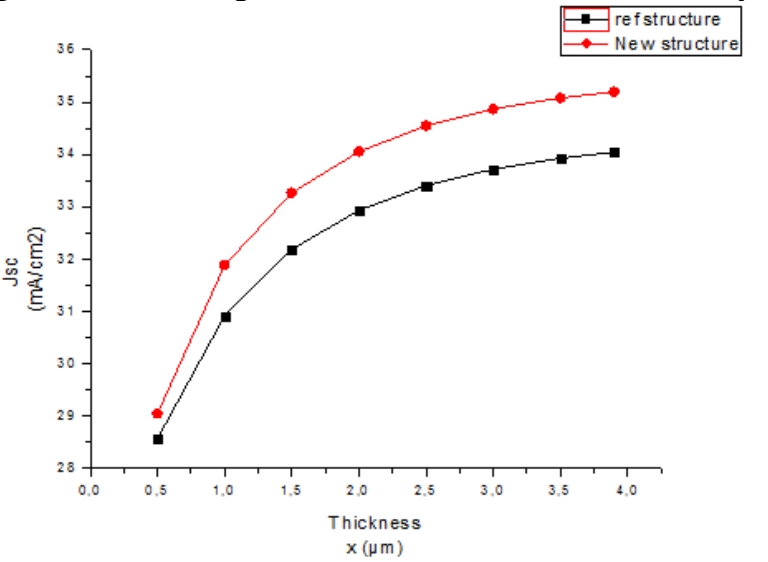

Figure 6. Changes in the short-circuit current vs. the thickness of the CIGS layer 
Table 5. Effect of different thicknesses of CdS

\begin{tabular}{|c|c|c|c|c|c|c|c|c|}
\hline \multirow{2}{*}{$\begin{array}{c}\text { Thickness X } \\
\text { (CdS) } \\
(\mu \mathrm{m})\end{array}$} & \multicolumn{2}{|c|}{ Efficiency $\eta(\%)$} & \multicolumn{2}{|c|}{ Filling factor FF (\%) } & \multicolumn{2}{|c|}{$\begin{array}{c}\text { Short-circuit current } \\
\text { Jsc }\left(\mathbf{m A} / \mathrm{cm}^{2}\right)\end{array}$} & \multicolumn{2}{|c|}{$\begin{array}{c}\text { Open circuit voltage } \\
\operatorname{Voc}(V)\end{array}$} \\
\hline & $\begin{array}{l}\text { Reference } \\
\text { structure }\end{array}$ & $\begin{array}{c}\text { New } \\
\text { structure }\end{array}$ & $\begin{array}{l}\text { Reference } \\
\text { structure }\end{array}$ & $\begin{array}{c}\text { New } \\
\text { structure }\end{array}$ & $\begin{array}{l}\text { Reference } \\
\text { structure }\end{array}$ & $\begin{array}{c}\text { New } \\
\text { structure }\end{array}$ & $\begin{array}{c}\text { Reference } \\
\text { structure }\end{array}$ & $\begin{array}{c}\text { New } \\
\text { structure }\end{array}$ \\
\hline 0.02 & 18.09 & 23.40 & 81.81 & 83.86 & 34.310611 & 35.200983 & 0.6444 & 0.7928 \\
\hline 0.03 & 18.00 & 23.32 & 81.76 & 83.83 & 34.168326 & 35.093693 & 0.6443 & 0.7927 \\
\hline 0.04 & 17.87 & 23.19 & 81.68 & 83.78 & 33.972845 & 34.928037 & 0.6441 & 0.7926 \\
\hline 0.05 & 17.71 & 23.02 & 81.57 & 83.72 & 33.720319 & 34.703438 & 0.6439 & 0.7924 \\
\hline
\end{tabular}

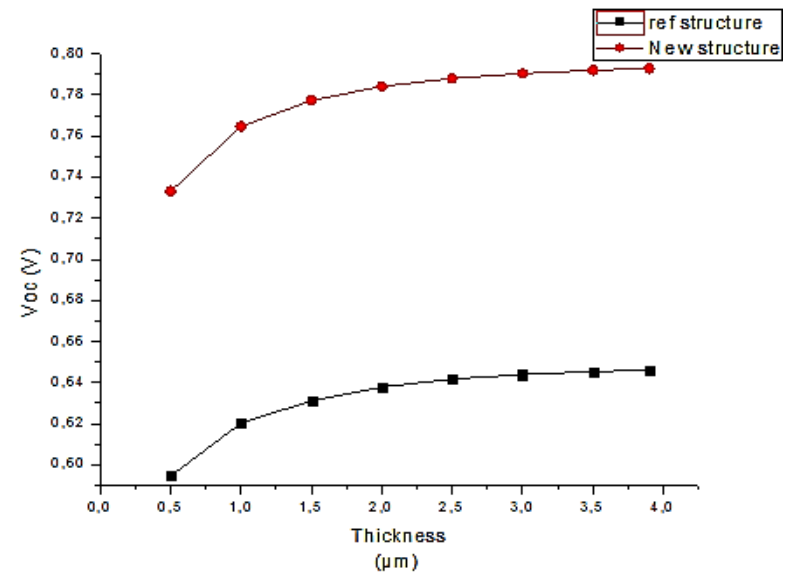

Figure 7. Changes in the open circuit voltage vs. the thickness of the CIGS layer

\subsection{Effect of the CdS-based buffer layer}

The CdS-based buffer layer consists of an N-type semiconductor whose forbidden band $\mathrm{Eg}$ is very wide compared to that of the CIGS absorber. This layer adapts the width of the forbidden band between the absorber and the window layer and limits the recombination of carriers at the interface of these two layers.

It also makes it possible to protect the surface of the absorber during the sputtering deposition of the $\mathrm{ZnO}$ layer, which can cause defects on the surface of the CIGS. However, $\mathrm{CdS}$ remains preferred because it always gives high yields.

However, its forbidden bandwidth, equal to relatively small, generates optical losses, so that significant quantities of light are absorbed before being able to reach the CIGS layer, even for CdS layers as thin as.

The photons absorbed in the CdS do not participate in the photocurrent, because of the short diffusion length of the minority carriers (holes) in the $\mathrm{CdS}$, which leads to a high rate of recombination.

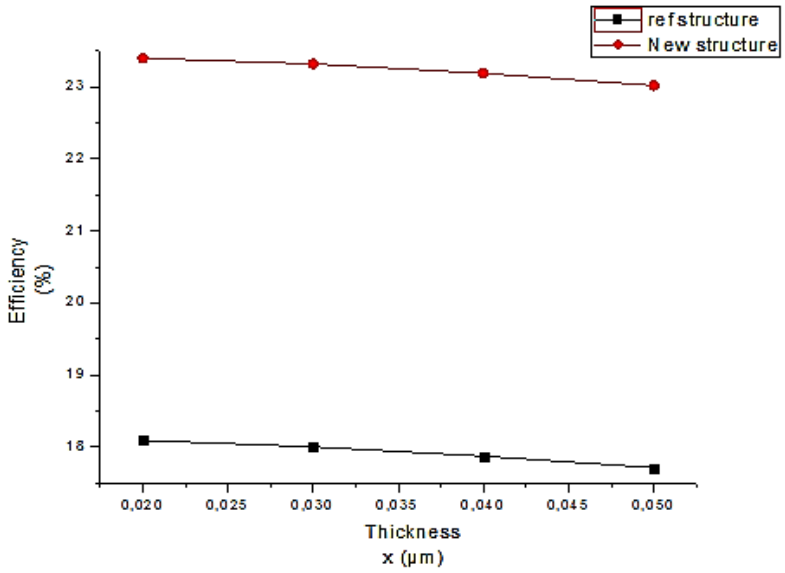

Figure 8. Changes in the Efficiency vs. the thickness of the CdS layer

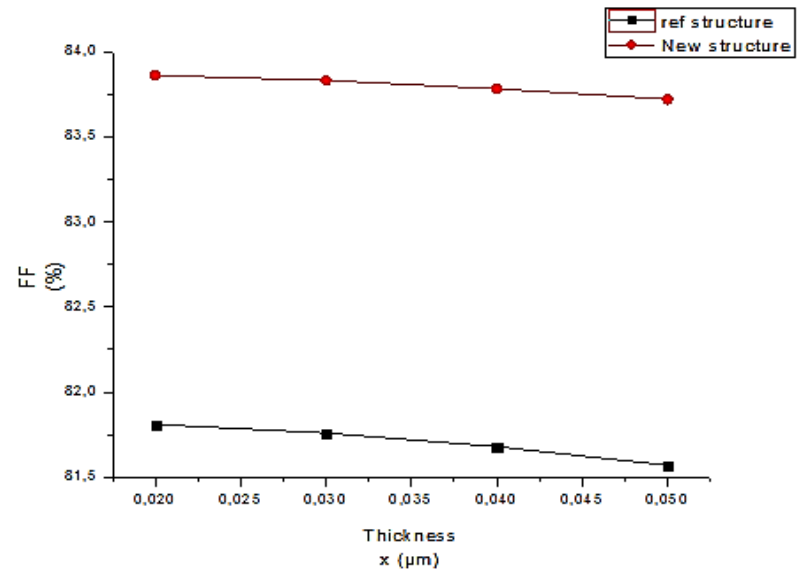

Figure 9. Changes in the Filling factor vs. the thickness of the CdS layer

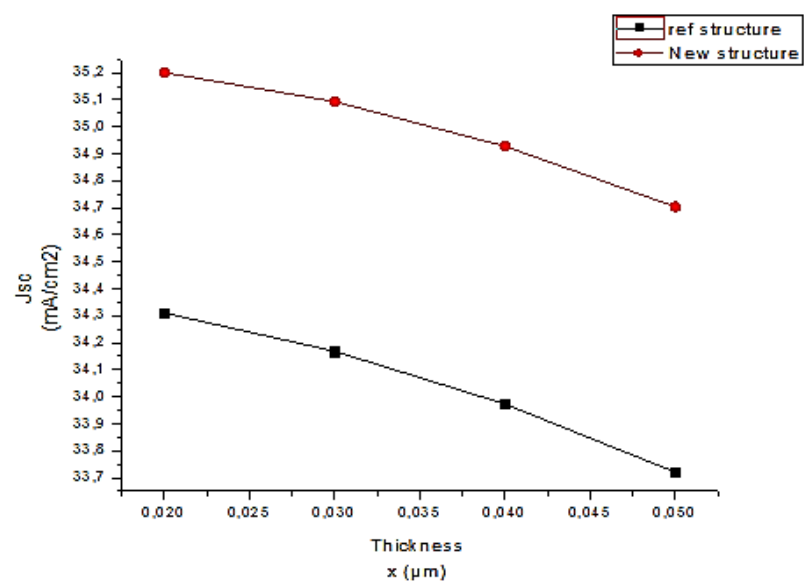

Figure 10. Changes in the short-circuit current vs. the thickness of the CdS layer

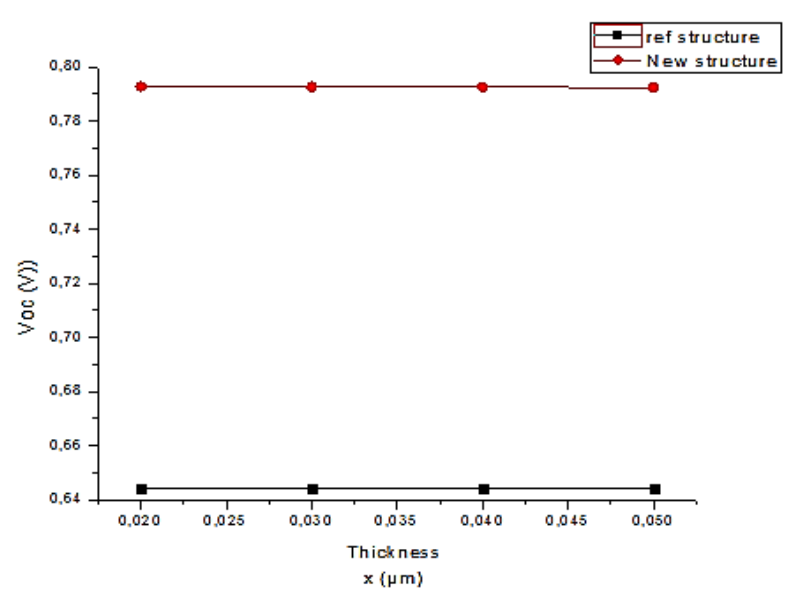

Figure 11. Changes in the short-circuit current vs. the thickness of the CdS layer 
Table 6. Effect of different thicknesses of $\mathrm{ZnO}$

\begin{tabular}{|c|c|c|c|c|c|c|c|c|}
\hline $\begin{array}{c}\text { Thickness } \\
\mathbf{X}(\mathbf{C d S})\end{array}$ & \multicolumn{2}{|c|}{ Efficiency $\boldsymbol{\eta}(\boldsymbol{\%})$} & \multicolumn{2}{c|}{ Filling factor FF $(\%)$} & \multicolumn{2}{c|}{$\begin{array}{c}\text { Short-circuit current } \\
\text { Jsc }\left(\mathbf{m A} / \mathbf{c m}^{2}\right)\end{array}$} & \multicolumn{2}{c|}{ Open circuit voltage Voc $(\mathbf{V})$} \\
\hline$(\mu \mathrm{m})$ & $\begin{array}{c}\text { Reference } \\
\text { structure }\end{array}$ & $\begin{array}{c}\text { New } \\
\text { structure }\end{array}$ & $\begin{array}{c}\text { Reference } \\
\text { structure }\end{array}$ & $\begin{array}{c}\text { New } \\
\text { structure }\end{array}$ & $\begin{array}{c}\text { Reference } \\
\text { structure }\end{array}$ & $\begin{array}{c}\text { New } \\
\text { structure }\end{array}$ & $\begin{array}{c}\text { Reference } \\
\text { structure }\end{array}$ & $\begin{array}{c}\text { New } \\
\text { structure }\end{array}$ \\
\hline 0.043 & 17.96 & 23.40 & 81.56 & 83.86 & 34.188191 & 35.200983 & 0.6443 & 0.7928 \\
\hline 0.05 & 17.94 & 23.37 & 81.56 & 83.86 & 34.144041 & 35.148259 & 0.6442 & 0.7927 \\
\hline 0.10 & 17.82 & 23.19 & 81.57 & 83.85 & 33.912543 & 34.895487 & 0.6441 & 0.7925 \\
\hline 0.15 & 17.75 & 23.10 & 81.57 & 83.84 & 33.789413 & 34.766966 & 0.6440 & 0.7924 \\
\hline 0.20 & 17.71 & 23.05 & 81.57 & 83.84 & 33.720319 & 34.693751 & 0.6439 & 0.7924 \\
\hline
\end{tabular}

For this reason, and in addition to the constraints linked to the use of Cadmium $(\mathrm{Cd})$ which is a toxic element, many studies are carried out to replace $\mathrm{CdS}$ by other materials, among them, one can quote $(\mathrm{OH}, \mathrm{S}), \mathrm{Zn}(\mathrm{O}, \mathrm{OH}), \mathrm{ZnS}$.

The changes in the efficiency vs. the thickness of the CdS layer is plotted in Figure 8, where a decrease in the efficiency is observed with increasing thickness of the CdS layer.

The changes in the filling factor vs. the thickness of the CdS layer is plotted in Figure 9. This figure shows that the filling factor is almost constant with increasing thickness of the $\mathrm{CdS}$ layer.

The changes in the short-circuit current vs. the thickness of the CdS layer is given in Figure 10. As remarked, the shortcircuit current decreases with increasing thickness of the CdS layer.

Figure 11 summarizes the changes in the open circuit voltage vs. the thickness of the CdS layer.

In additions, the effect of different thicknesses is highlighted in Table 6. As shown, the open circuit voltage is almost constant with increasing thickness of the CdS layer.

\subsection{Effect of the $\mathrm{ZnO}$ window layer}

One of the two electrodes is transparent to allow the transmission of light sufficiently at the $\mathrm{P}-\mathrm{N}$ junction region and towards the CIGS absorbent and conductive layer to transport the photocurrent generated by the solar cell to the external circuit.

This electrode is a thin layer of transparent conductive oxide (TCO), a thin lined metal grid (Ni-Al) is deposited on the window layer so as to reduce its series resistance and collect the charges generated by the device.

$\mathrm{Ni}$ acts as a bonding layer and allows to avoid the oxidation of $\mathrm{Al}$ linked to the underlying presence of TCO. TCO, generally used for CIGS cells, and Zinc oxide ( $\mathrm{ZnO}$ ) deposited by sputtering.

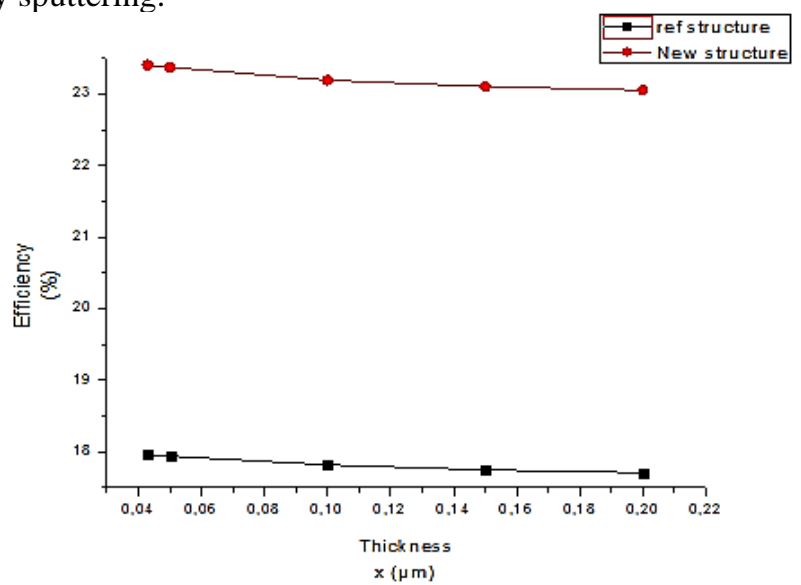

Figure 12. Changes in the efficiency vs. the thickness of the $\mathrm{ZnO}$ layer

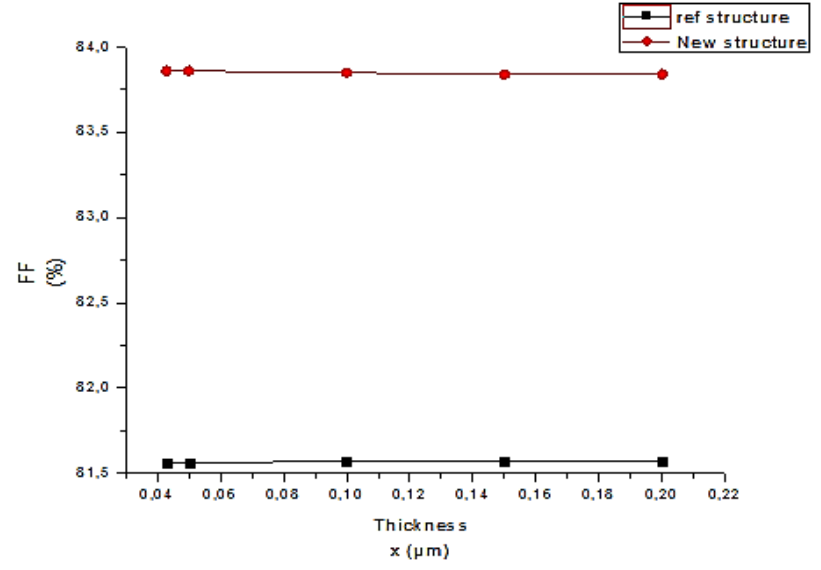

Figure 13. Changes in the Filling factor vs. the thickness of the $\mathrm{ZnO}$ layer

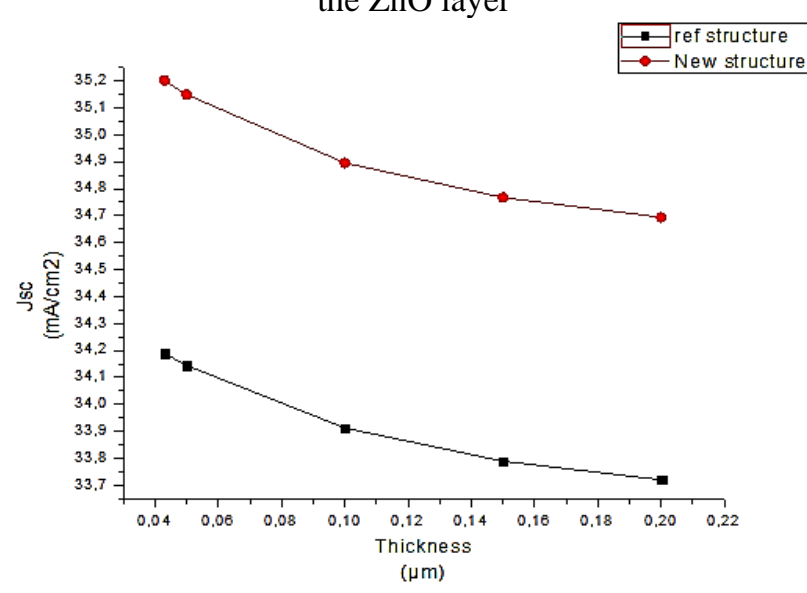

Figure 14. Changes in the short-circuit current vs. the thickness of the $\mathrm{ZnO}$ layer

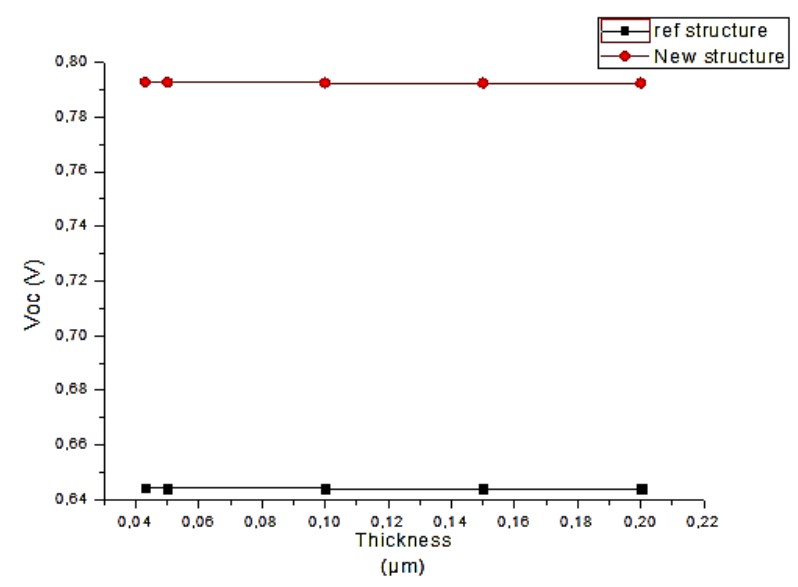

Figure 15. Changes in the Short-circuit current vs. the thickness of the $\mathrm{ZnO}$ layer 
The changes in the efficiency vs. the thickness of the $\mathrm{ZnO}$ layer is indicated in Figure 12. It is clearly illustrated that the efficiency decreases with increasing thickness of the $\mathrm{ZnO}$ layer.

Figure 13 claims the changes in the filling factor vs. the thickness of the $\mathrm{ZnO}$ layer. A shown, the filling factor is almost constant with increasing thickness of the $\mathrm{ZnO}$ layer.

Figure 14 illustrates the changes in the short-circuit current vs. the thickness of the $\mathrm{ZnO}$ layer. As observed, the shortcircuit current decreases with increasing thickness of the $\mathrm{ZnO}$ layer.

Figure 15 plots the changes in the open circuit voltage vs. the thickness of the $\mathrm{ZnO}$ layer. The figure shows that the open circuit voltage is almost constant with increasing thickness of the $\mathrm{ZnO}$ layer.

\section{CONCLUSION}

The numerical results obtained by the software SCAPS for a CIGS solar cell were highlighted. At the beginning, a structure model was chosen according to the literature to confirm the performance of our software and to establish a calculation code that is specific to the structures studied.

Then, the effects of the thickness of the three layers $\mathrm{ZnO}$, CdS and CIGS on the photovoltaic conversion efficiency $(\eta)$, the filling factor (FF); short-circuit current (Jsc), and open circuit voltage (Voc) were investigated.

The efficiency of the cell of 1stcase was found to be about $17.71 \%$, and the efficiency of the modified cell was equal to $23.40 \%$. We note that the thickness has a very significant impact on the improvement in the solar cell effectiveness.

Aiming to have a good performance, it is necessary to decrease the thickness of the $\mathrm{ZnO}$ window layer and the $\mathrm{CdS}$ buffer layer to increase the thickness of the CIGS absorber up to $3.9 \mu \mathrm{m}$.

\section{REFERENCES}

[1] Saïdi, H., Alaya, C.B., Boujmil, M.F., Durand, B., Lazzari, J.L., Bouaïcha, M. (2020). Physical properties of electrodeposited CIGS films on crystalline silicon: Application for photovoltaic hetero-junction. Current Applied Physics, 20(1): 29-36. https://doi.org/10.1016/j.cap.2019.09.015

[2] Hadjab, M., Ibrir, M., Berrah, S., Abid, H., Saeed, M.A. (2018). Structural, electronic and optical properties for chalcopyrite semiconducting materials: ab-initio computational study. Optik, 169: 69-76. https://doi.org/10.1016/j.ijleo.2018.05.044

[3] Madhuri, K., Kannan, P.K., Chaudhari, S., Dhage, S.R., Dey, S.R. (2020). Effect of annealing time and heat flux on solvothermal synthesis of CIGS nanoparticles. Materials Today: Proceedings, 21: 1882-1887. https://doi.org/10.1016/j.matpr.2020.01.245

[4] Mandati, S., Sarada, B.V. (2020). Electrodeposited chalcopyrite $\mathrm{CuInGaSe} 2$ absorbers for solar energy harvesting. Materials Science for Energy Technologies, 3: 440-445. https://doi.org/10.1016/j.mset.2020.03.001

[5] Ramasamy, M., Jung, C.Y., Yeon, Y.B., Lee, C.W. (2017). Electrochemical Atomic Layer Deposition of CuIn (1-x) GaxSe $\mathrm{Se}_{2}$ on Mo Substrate. Journal of The Electrochemical Society, 164(14): D1006. https://doi.org/10.1149/2.1231714jes

[6] Kotbi, A., Hartiti, B., Fadili, S., Labrim, H., Ridah, A., Thevenin, P. (2020). Synthesis and characterization of sprayed CIGS thin films for photovoltaic application. Materials Today: Proceedings, 24: 66-70. https://doi.org/10.1016/j.matpr.2019.07.537

[7] Sheu, H.H., Hsu, Y.T., Jian, S.Y., Liang, S.C. (2016). The effect of $\mathrm{Cu}$ concentration in the photovoltaic efficiency of CIGS solar cells prepared by coevaporation technique. Vacuum, 131: 278-284. https://doi.org/10.1016/j.vacuum.2016.07.008

[8] Jäger-Waldau, A. (2012). Progress in chalcopyrite compound semiconductor research for photovoltaic applications and transfer of results into actual solar cell production. In Practical Handbook of Photovoltaics (pp. 373-395). Academic Press. https://doi.org/10.1016/B978-0-12-385934-1.00011-8

[9] Tai, K.F., Kamada, R., Yagioka, T., Kato, T., Sugimoto, H. (2017). From 20.9 to $22.3 \% \mathrm{Cu}(\mathrm{In}, \mathrm{Ga})(\mathrm{S}, \mathrm{Se})_{2}$ solar cell: reduced recombination rate at the heterojunction and the depletion region due to K-treatment. Japanese Journal of Applied Physics, 56(8S2): 08MC03. https://doi.org/10.7567/JJAP.56.08MC03

[10] Kovacic, M., Krc, J., Lipovsek, B., Chen, W.C., Edoff, M., Bolt, P. J., Topic, M. (2019). Light management design in ultra-thin chalcopyrite photovoltaic devices by employing optical modelling. Solar Energy Materials and Solar Cells, 200: 10993. https://doi.org/10.1016/j.solmat.2019.109933

[11] Akhavan, V.A., Goodfellow, B.W., Panthani, M.G., Steinhagen, C., Harvey, T.B., Stolle, C.J., Korgel, B.A. (2012). Colloidal CIGS and CZTS nanocrystals: A precursor route to printed photovoltaics. Journal of Solid State Chemistry, $\quad 189$ : 2-12. https://doi.org/10.1016/j.jssc.2011.11.002

[12] Pluengphon, P., Bovornratanaraks, T., Vannarat, S., Pinsook, U. (2012). The effects of $\mathrm{Na}$ on high pressure phases of $\mathrm{CuIn} 0.5 \mathrm{Ga} 0.5 \mathrm{Se}_{2}$ from ab initio calculation. Journal of Physics: Condensed Matter, 24(9): 095802. https://doi.org/10.1088/0953-8984/24/9/095802

[13] Lara-Lara, B., Fernández, A.M. (2019). Growth improved of CIGS thin films by applying mechanical perturbations to the working electrode during the electrodeposition process. Superlattices and Microstructures, 128: 144-150. https://doi.org/10.1016/j.spmi.2019.01.024

[14] Park, S.J., Cho, Y., Moon, S.H., Kim, J.E., Lee, D.K., Gwak, J., Kim, J.Y., Kim, D.W., Min, B.K. (2014). A comparative study of solution-processed low-and highband-gap chalcopyrite thin-film solar cells. Journal of Physics D: Applied Physics, 47(13): 135105. https://orcid.org/0000-0002-5687-7739

[15] Jheng, B.T., Liu, P.T., Chang, Y.P., Wu, M.C. (2013). Polycrystalline $\mathrm{Cu}$ (In, Ga) $\mathrm{Se}_{2}$ thin films and PV devices sputtered from a binary target without additional selenization. ECS Transactions, 50(49): 53. https://doi.org/10.1149/05049.0053ecst

[16] Fu, Y.P., You, R.W., Lew, K.K. (2009). CuIn1- x Ga x $\mathrm{Se}_{2}$ Absorber Layer Fabricated by Pulse-Reverse Electrodeposition Technique for Thin Films Solar Cell. Journal of The Electrochemical Society, 156(12): D553. https://doi.org/10.1149/1.3240330

[17] Dharmadasa, I.M. (2009). Fermi level pinning and effects on CuInGaSe ${ }_{2}$-based thin-film solar cells. 
Semiconductor Science and Technology, 24(5): 055016. https://doi.org/10.1088/0268-1242/24/5/055016

[18] Liang, G.X., Fan, P., Cao, P.J., Zheng, Z.H., Zhang, D.P. (2013). Properties of CuInGaSe $\mathrm{C}_{2}$ thin-film prepared from multiple layers via ion beam sputtering method. ECS $\begin{array}{llll}\text { Solid } & \text { State } & \text { Letters, } & \text { 3(3): }\end{array}$ https://doi.org/10.1149/2.002403ssl

[19] Van Puyvelde, L., Lauwaert, J., Tempez, A., Devulder, W., Nishiwaki, S., Pianezzi, F., Detavernier, C., Tiwari, A.N., Vrielinck, H. (2015). Electronic defect study on low temperature processed $\mathrm{Cu}$ (In, $\mathrm{Ga}$ ) $\mathrm{Se}_{2}$ thin-film solar cells and the influence of an Sb layer. Journal of Physics D: Applied Physics, 48(17): 175104. https://doi.org/10.1088/0022-3727/48/17/175104

[20] Sobayel, K., Shahinuzzaman, M., Amin, N., Karim, M. R., Dar, M. A., Gul, R., Alghoul, M.A., Sopian, K., Hasan, A.K.M., Akhtaruzzaman, M. (2020). Efficiency enhancement of CIGS solar cell by $\mathrm{WS}_{2}$ as window layer through numerical modelling tool. Solar Energy, 207: 479-485. https://doi.org/10.1016/j.solener.2020.07.007

[21] Li, Y., Lin, H., Zeng, J., Chen, J., Chen, H. (2019). Enhance short-wavelength response of CIGS solar cell by $\mathrm{CdSe}$ quantum disks as luminescent down-shifting material. Solar Energy, 193: 303-308. https://doi.org/10.1016/j.solener.2019.09.071

[22] Farooq, W., Alshahrani, T., Kazmi, S.A.A., Iqbal, J., Khan, H.A., Khan, M., Raja, A.A., ur Rehman, A. (2021). Materials optimization for thin-film copper indium gallium selenide (CIGS) solar cell based on distributed braggs reflector. Optik, 227: 165987. https://doi.org/10.1016/j.ijleo.2020.165987

[23] Sharbati, S., Gharibshahian, I., Orouji, A.A. (2019). Designing of AlxGa1-xAs/CIGS tandem solar cell by analytical model. Solar Energy, 188: 1-9. https://doi.org/10.1016/j.solener.2019.05.074

[24] Bouchama, I., Boudour, S., Bouarissa, N., Rouabah, Z. (2017). Quantum and conversion efficiencies optimization of superstrate CIGS thin-films solar cells using In2Se3 buffer layer. Optical Materials, 72: 177-182. https://doi.org/10.1016/j.optmat.2017.05.056

[25] Saifullah, M., Moon, J.H., Ahn, S., Gwak, J., Ahn, S., Kim, K., Eo, Y.J., Yun, J.H. (2016). Effect of Cu content on the photovoltaic properties of wide bandgap CIGS thin-film solar cells prepared by single-stage process. Current Applied Physics, 16(11): 1517-1522. https://doi.org/10.1016/j.cap.2016.08.019

[26] Mallem, K., Kim, Y.J., Hussain, S.Q., Dutta, S., Le, A.H.T., Ju, M., Park, J., Cho, Y.H., Kim, Y., Cho, E.C., Yi, J. (2019). Molybdenum oxide: A superior hole extraction layer for replacing p-type hydrogenated amorphous silicon with high efficiency heterojunction $\mathrm{Si}$ solar cells. Materials Research Bulletin, 110: 90-96. https://doi.org/10.1016/j.materresbull.2018.10.018

[27] Ding, D., Lu, G., Li, Z., Zhang, Y., Shen, W. (2019). High-efficiency n-type silicon PERT bifacial solar cells with selective emitters and poly-Si based passivating contacts. Solar Energy, 193: 494-501. https://doi.org/10.1016/j.solener.2019.09.085

[28] Procel, P., Löper, P., Crupi, F., Ballif, C., Ingenito, A. (2019). Numerical simulations of hole carrier selective contacts in p-type c-Si solar cells. Solar Energy Materials and Solar Cells, 200: 109937. https://doi.org/10.1016/j.solmat.2019.109937

[29] Richter, A., Benick, J., Feldmann, F., Fell, A., Hermle, M., Glunz, S.W. (2017). n-Type Si solar cells with passivating electron contact: Identifying sources for efficiency limitations by wafer thickness and resistivity variation. Solar Energy Materials and Solar Cells, 173: 96-105. https://doi.org/10.1016/j.solmat.2017.05.042

[30] Tao, K., Li, Q., Hou, C., Jiang, S., Wang, J., Jia, R., Sun, Y., Li, Y.T., Jin, Z., Liu, X. (2017). Application of a$\mathrm{Si} / \mu \mathrm{c}-\mathrm{Si}$ hybrid layer in tunnel oxide passivated contact n-type silicon solar cells. Solar Energy, 144: 735-739. https://doi.org/10.1016/j.solener.2017.01.061

[31] Ok, Y.W., Upadhyaya, A.D., Tao, Y., Zimbardi, F., Ryu, K., Kang, M.H., Rohatgi, A. (2014). Ion-implanted and screen-printed large area $20 \%$ efficient N-type front junction Si solar cells. Solar Energy Materials and Solar Cells, 123: 92-96. https://doi.org/10.1016/j.solmat.2014.01.002

[32] Rajani, K.V., Daniels, S., Rahman, M., Cowley, A., McNally, P.J. (2013). Deposition of earth-abundant ptype $\mathrm{CuBr}$ films with high hole conductivity and realization of $\mathrm{p}-\mathrm{CuBr} / \mathrm{n}-\mathrm{Si}$ heterojunction solar cell. Materials Letters, 111: 63-66. https://doi.org/10.1016/j.matlet.2013.08.042

[33] Singh, S., Dross, F., Posthuma, N.E., Mertens, R. (2011). Large area $15.8 \%$ n-type mc-Si screen-printed solar cell with screen printed Al-alloyed emitter. Solar Energy Materials and Solar Cells, 95(4): 1151-1156. https://doi.org/10.1016/j.solmat.2010.12.043

[34] Jay, F., Muñoz, D., Desrues, T., Pihan, E., De Oliveira, V.A., Enjalbert, N., Jouini, A. (2014). Advanced process for n-type mono-like silicon a-Si: H/c-Si heterojunction solar cells with $21.5 \%$ efficiency. Solar Energy Materials and Solar Cells, 130: 690-695. https://doi.org/10.1016/j.solmat.2014.02.025

[35] Gloeckler, M., Sites, J.R., Metzger, W.K. (2005). Grainboundary recombination in $\mathrm{Cu}$ (In, Ga) $\mathrm{Se}_{2}$ solar cells. Journal of Applied Physics, 98(11): 113704. https://doi.org/10.1063/1.2133906 